Akreditasi KEMENRISTEKDIKTI, Nomor: 28/E/KPT/2019
http: / / jurnal.stkippersada.ac.id/jurnal/index.php/VoX

\title{
MENAKAR SISTEM ZONASI PENERIMAAN SISWA BARU DI ERA DESENTRALISASI PENDIDIKAN
}

\author{
Satrio Ageng Rihardi ${ }^{1}, \&$ Arnanda Yusliwidaka ${ }^{2}$ \\ ${ }^{1,2}$ Fakultas Ilmu Sosial dan Ilmu Politik, Universitas Tidar \\ Email: satrioagengrihardi@untidar.ac.id,papierarnanda@gmail.com
}

INFO ARTIKEL
Riwayat Artikel:
$\begin{array}{ll}\text { Menerima } & : 15 \text { Nopember } 2019 \\ \text { Revisi } & : 30 \text { Maret } 2020 \\ \text { Diterima } & : 20 \text { April } 2020\end{array}$

Kata Kunci:

Kebijakan, Zonasi, $P P D B$,

Desentralisasi

Keywords:

Policy, Zoning, PPDB,

Decentralization

\section{Korespondensi:}

Satrio Ageng Rihardi

Fakultas Ilmu Sosial dan Ilmu

Politik, Universitas Tidar

Email:

satrioagengrihardi@untidar.ac.id

\section{ABSTRAK}

Sistem pendidikan sesuai dengan UU Nomor 32 Tahun 2004 tentang Pemerintah Daerah kebijakan tentang desentralisasi diserahkan pada Pemerintah Daerah masing-masing. Khususnya dalam kebijakan jalur zonasi berpengaruh terhadap mutu penyelenggaraan pendidikan khususnya dalam perolehan jumlah siswa. Contohnya ada satu siswa di SMAN Kota Magelang terpaksa tidak dapat sekolah favorit, selain itu protes dari pihak orang tua murid. Penelitian secara normatif empiris yang dianalisis secara diskriptif kualitatif. Pemerintah wajib melaksanakan perbaikan secara berkesinambungan mengenai sistem nasional pendidikan di era desentralisasi melalui: Evaluasi kesiapan pemerintah daerah dalam sistem zonasi untuk mendata kecukupan sekolah; Pemerataan pendidikan dengan sarana dan prasarana yang memadai; Guru yang memadai untuk setiap zona; Ketersediaan informasi secara online maupun melalui pamflet dan papan pengumuman; Perlunya dipetakan dampak sistem zonasi. Jika memperhatikan hal tersebut, maka pelaksanaan kebijakan desentralisasi pendidikan dapat dikatakan lebih efektif dan efisien untuk dunia pendidikan di masa yang akan datang.

\section{ABSTRACT}

The education system is in accordance with Law Number 32 of 2004 concerning Regional Government. Policies on decentralization are left to the respective Regional Governments. Especially in the zoning policy policies affect the quality of the implementation of education, especially in the acquisition of the number of students. For example, there was one student in Magelang City High School who was forced to not get a favorite school, besides protesting from the parents. Empirical normative research that is analyzed by descriptive qualitative. The government is obliged to carry out continuous improvement of the national education system in the decentralization era through: Evaluation of the readiness of local governments in the zoning system to record the adequacy of schools; Equitable education with adequate facilities and infrastructure; Adequate teachers for each zone; Availability of information online as well as through pamphlets and bulletin boards; The need to map the impact of the zoning system. If you pay attention to this, then the implementation of education decentralization policy can be said to be more effective and efficient for the world of education in the future.

(C)2020 LPPM STKIP PersadaKhatulistiwa Sintang

\section{PENDAHULUAN}

Negara Indonesia selalu berupaya untuk menjadi negara maju dalam bidang pendidikan. Negara Indonesia mengeluarkan pengaturan sistem pendidikan Nasional yakni UndangUndang Nomor 20 Tahun 2003 tentang Sistem
Pendidikan Nasional (UU SISDIKNAS). Visi dari UU SISDIKNAS terwujudnya sistem pendidikan sebagai pranata sosial yang kuat dan berwibawa untuk memberdayakan semua warga Negara Indonesia berkembang menjadi manusia yang berkualitas sehingga mampu dan 
proaktif menjawab tantangan zaman yang selalu berubah. Pendidikan dimaknai harus mengintregasikan terhadap seluruh komponen yang ada dalam pendidikan seperti lingkungan, masyarakat, dan sumber daya. Ini dilakukan untuk memperoleh umpan balik dari seluruh komponen yang ada, sehingga dapat dijadikan evaluasi perubahan dalam sistem pendidikan nasional.

Seiring perkembangan zaman mendasarkan kebutuhan komponen masyarakat, sistem pendidikan dikelola secara terpusat yang berlaku di seluruh tanah air. Pemusatan pendidikan mengatur mengenai tujuan dari pendidikan, materi ajar, metode pembelajaran, buku ajar bahkan sampai sistem pengelolaan penerimaan siswa baru. Pemerintah yang memiliki kekuasaan penuh dalam menentukan kebijakan termasuk kebijakan perubahan sistem sentralisasi menjadi desentralisasi yang saat ini menjadi trend. Secara umum, desentralisasi didefinisikan sebagai pemberian (transfer) wewenang dan tanggung jawab penanganan fungsi publik dari pemerintah pusat kepada pemerintah daerah. Kebijakan desentralisasi dimulai sejak ditetapkannya UU Nomor 23 Tahun 2014 sebagai perubahan dari UU Nomor 32 Tahun 2004 tentang Pemerintah Daerah. Melalui desentralisasi, pemerintah daerah akan lebih banyak berperan dalam melihat kebutuhan masyarakat termasuk dalam penyelenggaraan pendidikan. Pemerintah daerah melalui Dinas Pendidikan setempat dapat memiliki kewenangan penuh dalam pengelolaan penyelenggaraan pendidikan khususnya sistem penerimaan siswa baru.
Desentralisasi diartikan sebagai pemindahan sebagian kekuasaan pemerintah pusat kepada pemerintah daerah atau lokal. Pengertian ini menggambarkan sejumlah pembaharuan yang bertujuan untuk meningkatkan suara lokal dalam kebijakan. Untuk desentralisasi pendidikan merupakan salah satu upaya pendelegasian sebagian atau seluruh wewenang di bidang pendidikan yang seharusnya dilakukan oleh pemerintah pusat kepada pemerintah daerah atau dari pemerintah kepada masyarakat.

Kebijakan Dinas Pendidikan di Kota Magelang dalam penerimaan siswa baru tingkat SMA tetap merujuk pada ketentuan dari Peraturan Menteri Pendidikan dan Kebudayaan Nomor 14 Tahun 2018 Tentang Penerimaan Peserta Didik Baru Pada TK, SD, SMP, SMA, SMK atau Bentuk Lain yang Sederajat. Sedangkan di dalam Peraturan Menteri Pendidikan Kebudayaan Nomor 20 Tahun 2019 terdapat tiga jalur pendaftaran PPDB yang meliputi jalur zonasi, jalur prestasi, dan jalur perpindahan tugas orang tua/wali. Untuk jalur zonasi paling sedikit adalah $80 \%$ dari daya tampung sekolah, untuk jalur prestasi sebanyak $15 \%$ dan Jalur perpindahan tugas orang tua/wali paling banyak 5\%. Berkaitan dengan masalah zonasi seleksi calon didik baru untuk kelas 10 SMA Negeri, pemerintah daerah wajib menerima calon peserta didik pada radius zona $90 \%$, sedangkan untuk diluar radius zona menerima paling banyak 5\% untuk jalur prestasi dan 5\% untuk jalur alasan khusus dari total jumlah yang diterima. Sedangkan di dalam Peraturan Menteri Pendidikan Kebudayaan Nomor 20 Tahun 2019 terdapat tiga jalur 
pendaftaran PPDB yang meliputi jalur zonasi, jalur prestasi, dan jalur perpindahan tugas orang tua/wali. Untuk jalur zonasi paling sedikit adalah $80 \%$ dari daya tampung sekolah, untuk jalur prestasi sebanyak 15\% dan Jalur perpindahan tugas orang tua/wali paling banyak 5\%. Tentu saja hal ini menjadi permasalahan bagi calon peserta didik baru dalam memilih sekolah sasaran. Seperti yang terjadi di SMA N 1 dan SMA N 4 Kota Magelang, ternyata jika disesuaikan dengan radius zonasi tidak banyak peserta didik yang diterima. Tentu saja ini berpengaruh terhadap mutu penyelenggaraan pendidikan khususnya dalam perolehan jumlah siswa baru. Selain itu, menurut penuturan dari Plh. Kepala Cabang Dinas Wilayah VIII Muh. Zubaidi menyatakan bahwa terdapat masalah terhadap salah satu siswa yang tidak memperoleh sekolah tujuan akibat sudah terpenuhinya kuota penerimaan siswa baru, sehingga dengan terpaksa siswa tersebut beralih ke sekolahan swasta. Masalah selanjutnya adalah mengenai protes dari pihak orang tua murid yang dianggap bahwa kebijakan sistem zonasi sangat merugikan dan tidak mencerminkan keadilan.

Dari kebijakan tersebut, dipandang penting untuk dilakukan evaluasi dan penilaian prestasi desentralisasi yang kaitannya dengan upaya dalam meningkatkan mutu penyelenggaraan pendidikan tingkat SMA Negeri di Kota Magelang. Penelitian ini bertujuan khusus untuk mengukur bagaimana pengaruh kebijakan desentralisasi pendidikan terhadap peningkatan mutu penyelenggaraan pendidikan di Kota Magelang. Sehingga, tim penelitian tertarik untuk melakukan penelitian dengan judul "Menakar Sistem Zonasi Penerimaan Siswa Baru di Era Desentralisasi Pendidikan”. Rumusan Masalah

1. Apakah pelaksanaan kebijakan desentralisasi pendidikan dapat berpengaruh secara signifikan terhadap jumlah penerimaan siswa baru?

2. Bagaimana upaya Dinas Pendidikan untuk menakar sistem zonasi penerimaan siswa baru di era desentralisasi pendidikan?

3. Apakah pelaksanaan kebijakan desentralisasi pendidikan dapat efektif dan efisien untuk dunia pendidikan di masa yang akan datang?

\section{METODE PENELITIAN}

Penelitian yang akan dilaksanakan ini menggunakan metode penelitian hukum Nomorrmatif atau penelitian hukum kepustakaan. Metode penelitian ini dilakukan dengan cara meneliti bahan pustaka yang dikumpulkan oleh peneliti dan dilakukan dengan seksama serta melalui pencarian yang sesuai dengan tema. Setelah bahan pustaka terkumpul peneliti melakukan kajian terhadap bahan pustaka tersebut secara komprehensif, sehingga metode ini menghasilkan suatu penelitian yang objektif dan berkualitas.

Bahan penelitian yang digunakan adalah bahan kepustakaan yang terdiri dari bahan primer, sekunder, dan tersier:

1. Bahan primer:

a. Undang-Undang Nomor 20 Tahun 2003 tentang Sistem Pendidikan Nasional

b. Undang-Undang Nomor 23 Tahun 2014 tentang Pemerintahan Daerah 
c. Peraturan Menteri Pendidikan dan Kebudayaan Nomor 14 Tahun 2018 tentang Penerimaan Peserta Didik Baru pada Taman Kanak-Kanak, Sekolah Dasar, Sekolah Menengah Pertama, Sekolah Menengah Atas, Sekolah Menengah Kejuruan, atau Bentuk Lain yang Sederajat

d. Peraturan Daerah Kota Magelang Nomor 11 Tahun 2016 tentang Sistem Penyelenggaraan Pendidikan

e. Peraturan Daerah Kota Magelang Nomor 2 Tahun 2010 tentang Sistem Penyelenggaraan Pendidikan

f. Peraturan Menteri Pendidikan dan Kebudayaan Nomor 51 Tahun 2018 tentang Penerimaan Peserta Didik Baru

g. Peraturan Menteri Pendidikan Kebudayaan Nomor 20 Tahun 2019 terdapat tiga jalur pendaftaran Penerimaan Peserta Didik Baru

2. Bahan sekunder, karya tulis ilmiah para ahli hukum berkualifikasi tinggi, hasil penelitian, jurnal, buku, dokumen, jawaban narasumber.

3. Bahan tersier, bahan yang menunjang bahan hukum primer dan sekunder untuk membantu peneliti dalam melakukan kajian terhadap penelitian ini.

Teknik pencarian dalam penelitian ini adalah mengunakan studi pustaka. Instrumen untuk mencari data dalam penelitian dengan cara mengumpulkan data dan informasi yang berupa bahan hukum primer, yaitu bahan hukum yang mengikat dari penelitian ini, maupun bahan hukum sekunder, yaitu bahan hukum yang terdiri atas literatur yang ditulis oleh para ahli yang berhubungan dengan desentralisasi pendidikan. Penelitian ini juga menggunakan metode wawancara terhadap narasumber yang mempunyai kompetensi dibidang kajian ini. Teknik wawancara terhadap narasumber ini yaitu dengan mengajukan beberapa pertanyaan kepada narasumber yang nantinya jawaban tersebut membantu peneliti dalam melengkapi jawaban yang dirumuskan oleh peneliti.

Keseluruhan data yang diperoleh dianalisis secara diskriptif kualitatif yaitu kesesuaian analisis dengan suatu ukuran yang berupa keharusan dipenuhinya persyaratan kualitas tertentu, mengenai kebijakan dari Kementrian Pendidikan dan Kebudayaan terkait sistem zonasi bagi penerimaan siswa baru yang menurut hipotesa peneliti terdapat permasalahan dengan konsep desentralisasi pendidikan. Hasil analisis dapat dijadikan pedoman untuk menganalisa Peraturan Menteri Pendidikan dan Kebudayaan Republik Indonesia Nomor 14 Tahun 2018 tentang Penerimaan Peserta Didik Baru pada TK, SD, SMP, SMA, SMK, atau Bentuk Lain yang Sederajat. Analisis dimulai dengan pengumpulan data dari sumber bahan penelitian. Langkah selanjutnya hasil wawancara narasumber dikaji untuk dijadikan sebagai rujukan dalam menganalisis masalah. Output dari analisis dalam penelitian ini adalah sebuah kajian akademis yang dapat dijadikan rekomendasi bagi stakeholders di Kota Magelang terkait sistem zonasi dalam penerimaan siswa baru. 


\section{HASIL DAN PEMBAHASAN}

1. Pengaruh Pelaksanaan Kebijakan Sistem Zonasi Penerimaan Siswa Baru Di Era Desentralisasi

Desentralisasi diartikan sebagai pemindahan sebagian kekuasaan pemerintah pusat kepada pemerintah daerah atau lokal. Pengertian ini menggambarkan sejumlah pembaharuan yang bertujuan untuk meningkatkan suara lokal dalam kebijakan. Apabila sentralisasi merupakan respon terhadap kebutuhan untuk persatuan nasional, maka desentralisasi adalah tanggapan atas tuntutan terhadap keberagaman. Hal ini mengartikan bahwa pemerintah menyadari bahwa aspek lokalitas dalam menyelenggarakan pendidikan adalah suatu keniscayaan. Desentralisasi pendidikan adalah upaya pendelegasian sebagian atau seluruh wewenang di bidang pendidikan yang seharusnya dilakukan oleh pemerintah pusat kepada pemerintah daerah atau dari pemerintah kepada masyarakat.

Desentralisasi pendidikan bertujuan untuk mengurangi campur tangan atau intervensi pejabat atau unit pusat terhadap persoalan pendidikan yang sepatutnya bisa diputuskan dan dillaksanakan oleh unit tataran bawah atau masyarakat. Dengan demikian desentralisasi pendidikan ini juga bertujuan untuk memberikan peranan unit bawah atau masyarakat dalam menangani persoalan pendidikan di bawah.

Kementerian Pendidikan Nasional merumuskan desentralisasi pendidikan dalam dua kategori. Pertama, desentralisasi pendidikan dalam arti desentralisasi pemerintahan dalam bidang pendidikan yang diharapkan dapat mewujudkan pemerintahan daerah yang otonom dalam pengelolaan pendidikan. Kedua adalah desentralisasi pada satuan pendidikan yang bertujuan untuk mewujudkan lembaga/satuan pendidikan yang mandiri dan profesional. Konsep desentralisasi pendidikan sendiri diharapkan dapat mencapai pengelolaan pendidikan yang efisien, demokratis dan berkeadilan.

Dalam konsep desentralisasi pendidikan ini ada memiliki tiga nilai yang ingin diwujudkan dalam sektor pendidikan, yaitu sebagai berikut: pertama, sebagai upaya untuk mendekatkan pengambilan keputusan yang selama ini terlalu jauh. Kedua, untuk menyesuaikan pembangunan pendidikan agar lebih sesuai dengan kekhasan daerah. Ketiga, untuk lebih mendayagunakan potensi masyarakat yang sangat besar. Ketiga value ini diharapkan dapat meningkatkan peranan pendidikan dalam kaitannya dengan peningkatan mutu dan relevansi, efisiensi manajemen dan pemerataan akses Pendidikan bagi seluruh lapisan masyarakat.

Proses Pendidikan merupakan hal yang wajib untuk dilalui oleh setiap manusia sebagai petunjuk bagi keberlangsungan kehidupan yang sesuai dengan tata nlai ideologis dan kultural bangsa. Pendidikan dapat memberikan kesadaran kepada setiap individu akan potensi yang dimilikinya dan akan merangsang individu peserta didiknya untuk mempergunakan potensi tersebut 
sesuai dengan tata nilai kemanusiaan. Pendidikan juga akan memberikan pengetahuan yang memajukan dan mempertinggi kualitas hidup baik untuk pribadi, masyarakat dan bernegara.

Selain itu, implementasi sistem pendidikan nasional di Indonesia tergantung dari paradigma tata pemerintahan yang dikembangkan. Menurut Thoha (1999: 1-7), dengan adanya perubahan paradigma dari sentralisasi kekuasaan menjadi desentralisasi kewenangan, visi pendidikan pada masa depan harus berorientasi pada aspirasi dan kebutuhan Inasyarakat. Terkait dengan otonomi daerah desentralisasi pendidikan harus dapat menjawab situas, kebutuhan, dan nilai-nilai yang berkelnbang di daerah. Hal itu sejalan dengan pendapat Satori (1999: 1-22) bahwa para perencana dan pengelola pendidikan dipersyaratkan memiliki kemampuan untuk mengkaji masalah-masalah pendidikan strategik dalam konteks pembangunan kewilayahan.

Dalam menghadapi tantangan perubahan lingkungan yang terjadi dengan cepat dan seringkali tidak diperkirakan sebelumnya, para pimpinan perlu memberikan tanggapan, Minimal dalam tiga hal (Bryson, 1999: 66) sebagai berikut:

a. Organisasi harus berpikir secara strategis

b. Harus diterjemahkan pemikiran menjadi strategi yang efektif dalam menghadapi perubahan lingkungan.

c. Harus dapat dikembangkan pemikiran d. yang diperlukan dalam rangka mendasari perumusan dan penetapan strategis

Pemerintah memiliki kewajiban untuk menyelenggarakan proses pendidikan bagi warga negaranya dengan sebaik-baiknya, ini disebutkan dalam Undang-Undang Sistem Pendidikan Nasional Pasal 11 butir (1) yakni pemerintah dan pemerintah daerah wajib memberikan layanan dan kemudahan, serta menjamin terselenggaranya pendidikan yang bermutu bagi setiap warga negara tanpa diskriminasi. Ini juga diperkuat di dalam Undang-Undang Dasar tahun 1945 dalam tujuannya yakni "mencerdaskan kehidupan bangsa".

Penerimaan Peserta Didik Baru (PPDB) bertujuan untuk menjamin penerimaan peserta didik baru berjalan secara objektif, transparan, akuntabel, Nomorndiskriminatif, dan berkeadilan dalam rangka mendorong peningkatan akses layanan pendidikan. Pada tahun 2018 Pemerintah Pusat melalui Kementerian Pendidikan dan Kebudayaan menerbitkan Peraturan Menteri Pendidikan dan Kebudayaan Nomor 14 Tahun 2018.

Salah satu perubahan mendasar sistem penerimaan peserta didik baru yang diatur dalam Peraturan Pemerintah Pendidikan dan Kebudayaan Nomor 14 Tahun 2018 adalah adanya sistem zonasi. Sekolah yang diselenggarakan oleh pemerintah daerah wajib menerima calon peserta didik yang berdomisili pada radius zona terdekat dari Sekolah paling sedikit sebesar 90\% (sembilan puluh persen) dari total jumlah 
keseluruhan peserta didik yang diterima. Domisili calon peserta didik berdasarkan alamat pada kartu keluarga yang diterbitkan paling lambat 6 (enam) bulan sebelum pelaksanaan PPDB.

Melalui pendidikan akan meningkatkan kualitas SDM setiap individu. Kualitas SDM akan menjadi dasar utama dalam menambah wawasan dan ilmu pengetahuan yang akan membentuk karakter penerus bangsa yang siap dalam menghadapi situasi apapun. Seiring dengan perkembangan zaman, pemerintah perlu untuk melaksanakan perbaikan secara berkesinambungan terhadap semua komponen yang ada pada sistem nasional pendidikan. Sehingga, pendidikan nasional dapat tercapai dengan disusunnya suatu strategi yang berkaitan dengan permasalahan pendidikan di Indonesia. Permasalah-permasalahan pendidikan di Indonesia sekarang ini meliputi permasalahan mutu pendidikan, pemerataan pendidikan dan manajemen pendidikan. Hal yang paling penting dalam dunia pendidikan adalah kurangnya pemerataan mutu pendidikan hampir di setiap negara. Di Indonesia menjadi suatu masalah yang sangat jelas dan nyata dalam kesenjangan mutu pendidikan hampir di setiap daerah.

Khususnya untuk penerimaan peserta didik baru yang kemudian disingkat menjadi PPDB tingkat SMA Negeri di daerah Kota Magelang, Provinsi Jawa Tengah. Tata cara pelasanaan PPDB telah diatur dalam Peraturan Menteri Pendidikan dan Kebudayaan Nomor 51 Tahun 2018 tentang
Penerimaan Peserta Didik Baru. Sedangkan di dalam Peraturan Menteri Pendidikan Kebudayaan Nomor 20 Tahun 2019 terdapat tiga jalur pendaftaran PPDB yang meliputi jalur zonasi, jalur prestasi, dan jalur perpindahan tugas orang tua/wali. Untuk jalur zonasi paling sedikit adalah $80 \%$ dari daya tampung sekolah, untuk jalur prestasi sebanyak 15\% dan Jalur perpindahan tugas orang tua/wali paling banyak 5\%.

Untuk penerimaan siswa baru di Kota Magelang, Jawa Tengah berdasarkan keterangan dari Bapak Muh. Zubaidi selaku Pelaksana Harian Kepala Kantor Cabang Dinas Pendidikan Wilayah VIII, mengatakan bahwa untuk PPDB di Kota Magelang di tingkat SMA Negeri yang terdiri dari SMA N 1, SMA N 2, SMA N 3 , SMA N 4, SMA N 5 Kota Magelang tidak terjadi suatu permasalahan yang signifikan terhadap adanya sistem zonasi di era desentralisasi pendidikan. Terbukti adanya data yang ada di dalam situs

Namun, beliau mengatakan permasalahan itu dikarenakan dari sisi sarana dan prasarana yang kurang memadai, selain itu juga mengenai adanya salah satu siswa yang akan mendaftar di SMA tujuan tidak dapat diterima karena sudah penuh untuk daya tampungnya, sehingga dengan terpaksa siswa tersebut harus mencari sekolah lain yang berstatus swasta yang mana sekolah swasta tidak menerapkan sistem zonasi. Melihat hal tersebut, sangatlah jelas bahwa sekolah yang menjadi bagian utama dalam proses bahwa sekolah yg menjadi bagian 
utama dalam proses berjalannya pendidikan belum sesuai dengan Standar Nasional Pendidikan. Artinya peran pemerintah pun masih belum optimal dalam melakukan pemerataan kualitas dan mutu pendidikan. Akibatnya saat proses penerimaan siswa baru para siswa cenderung mendafatar di satu sekolah yg diunggulkan di daerah masing-masing. Dan hal ini semakin memperjelas bahwa pendidikan di indonesia masih adanya ketimpangan kualitas pendidikan.

Ini menjadi suatu pengaruh yang signifikan terhadap jumlah peserta didik yang akan mendaftar di SMA Negeri khususnya yang terdiri dari SMA N 1, SMA N 2, SMA N 3, SMA N 4, SMA N 5 Kota Magelang.

\begin{tabular}{|c|c|c|c|}
\hline $\begin{array}{c}\text { SMA } \\
\text { NEGERI }\end{array}$ & $\begin{array}{c}\text { TA } \\
\mathbf{2 0 1 7 / 2 0 1 8}\end{array}$ & $\begin{array}{c}\text { TA } \\
\mathbf{2 0 1 8} / \mathbf{2 0 1 9}\end{array}$ & $\begin{array}{c}\text { TA } \\
\mathbf{2 0 1 9} / \mathbf{2 0 2 0}\end{array}$ \\
\hline \multirow{2}{*}{ SMA 1 } & 887 & 892 & 952 \\
\cline { 2 - 4 } & $\mathbf{3 2 , 4 8 \%}$ & $\mathbf{3 2 , 6 6 \%}$ & $\mathbf{3 4 , 8 6 \%}$ \\
\hline \multirow{2}{*}{ SMA 2 } & 751 & 777 & 795 \\
\cline { 2 - 4 } & $\mathbf{3 2 , 3 3 \%}$ & $\mathbf{3 3 , 4 5 \%}$ & $\mathbf{3 4 , 2 2 \%}$ \\
\hline \multirow{2}{*}{ SMA 3 } & 725 & 738 & 785 \\
\cline { 2 - 4 } & $\mathbf{3 2 , 2 5 \%}$ & $\mathbf{3 2 , 8 3 \%}$ & $\mathbf{3 4 , 9 2 \%}$ \\
\hline \multirow{2}{*}{ SMA 4 } & 827 & 844 & 866 \\
\cline { 2 - 4 } & $\mathbf{3 2 , 6 0 \%}$ & $\mathbf{3 3 , 2 7 \%}$ & $\mathbf{3 4 , 1 3 \%}$ \\
\hline \multirow{2}{*}{ SMA 5 } & 768 & 780 & 854 \\
\cline { 2 - 4 } & $\mathbf{3 1 , 9 7 \%}$ & $\mathbf{3 2 , 4 7 \%}$ & $\mathbf{3 5 , 5 5 \%}$ \\
\hline
\end{tabular}

Tabel 1. Penerimaan peserta didik Data dari https://dapo.dikdasmen.kemdikbud.go.id/pr ogres-sma/2/036000

Ini diperkuat dengan pernyataan dari Bapak Muh. Zubaidi bahwasannya memang ada pengaruh yang siginifikan dalam penerimaan peserta didik khususnya di Tingkat SMA, yang sebelum ada sistem zonasi sekolah favorit akan memiliki peserta didik yang sesuai dengan daya tampung, dan setelah dari adanya sistem zonasi memang ada beberapa SMA Negeri yang kekurangan jumlah siswa namun telah memperlihatkan adanya pemerataan jumlah siswa peserta didik di tingkat SMA Negeri di Kota Magelang.

2. Peran Kantor Cabang Dinas Pendidikan Wilayah VIII dalam menakar sistem zonasi penerimaan siswa baru di era desentralisasi pendidikan

Dinamika kemajuan teknologi informasi dan komunikasi yang telah menjadi bagian dari kehidupan keseharian masyarakat pendidikan pada umumnya, harus mampu pula diikuti oleh penyedia layanan pendidikan, baik itu Pemerintah, Pemerintah Daerah, maupun oleh Salah satu upaya atas pemanfaatan kemajuan teknologi informasi dimaksud, antara lain dengan implementasi layanan Penerimaan Peserta Didik Baru (PPDB) Daring. PPDB daring untuk SMA Negeri dan SMK Negeri di Jawa Tengah Tahun Pelajaran 2019/2020 memang bukan merupakan kali yang bertama, dua tahun sebelumnya juga telah dilaksanakan dengan berbagai dinamikamya, Langkah ini dipilih tentunya bukan tanpa alasan. Alasan utama bagi Pemerintah Provinsi Jawa Tengah adalah agar masyarakat mendapatkan kemudahan dalam kerangka pemanfaatan kemajuan ilmu dan teknologi. Sistem PPDB Daring yang dirancang secara real time (basic waktu) tentu akan memberikan banyak kesempatan bagi masyarakat pengguna dalam menentukan pilihan studi lanjut bagi calon peserta didik, maupun bagi para orang tua yang melaksanakan tanggungjawab terhadap pendidikan putra dan putrinya. 
Sebagai tindak lanjut adanya kebijakan Permendikbud Nomor 51 Tahun 2018 jo Permendikbud Nomor 20 Tahun 2019, Pemerintah Provinsi Jawa Tengah kemudian menindaklanjuti melalui Gubernur dengan menerbitkan Peraturan Gubernur Jawa Tengah Nomor 9 Tahun 2019 tentang Penerimaan Peserta Didik Pada Sekolah Menengah Atas (SMA) Dan Sekolah Menengah Kejuruan (SMK) Negeri di Provinsi Jawa Tengah yang kemudian oleh Kepala Dinas Pendidikan Dan Kebudayaan Provinsi Jawa Tengah nmengeluarkan beschikking berupa Keputusan Kepala Dinas Pendidikan Dan Kebudayaan Provinsi Jawa Tengah Nomor : 421/07651 Tentang Petunjuk Teknis Penerimaan Peserta Didik Baru (PPDB) Pada Sekolah Menengah Atas (SMA) Dan Sekolah Menengah Kejuruan (SMK) Negeri Provinsi Jawa Tengah Tahun Pelajaran 2019/2020.

Salah satu upaya untuk peningkatan dan pemerataan kualitas pendidikan di Indonesia yaitu dengan diaplikasikannya sistem zonasi pada Penerimaan Peserta Didik Baru. Ketentuan sistem zonasi yg dimuat dalam PPDB ini bertujuan untuk menjamin penerimaan peserta didik baru berjalan dengan objektif, akuntabel, transparan dan tanpa diskriminasi sehingga mendorong peningkatan akses layanan pendidikan.

Sistem zonasi merupakan sistem penerimaan peserta didik baru yang diberlakukan dengan penentuan radius zona oleh pemerintah daerah masing-masing dan Sekolah wajib menerima calon peserta didik yang berdomisili pada radius zona terdekat dengan persentase tertentu dari total jumlah peserta didik yang akan diterima. Ini dilaksanakan juga untuk menghilangkan predikat sekolah favorit dan tidak favorit, agar tercipta pemerataan kualitas pendidikan di seluruh sekolah di Indonesia. Kebijakan penerimaan siswa berbasis zonasi pada awalnya mengalokasikan minimal 90\% kuota sekolah negeri untuk menerima calon siswa berdasarkan jarak rumah-kesekolah dan $10 \%$ sisanya untuk prestasi dan perpindahan. Namun kebijakan kuota siswa diubah oleh Kementerian Pendidikan dan Kebudayaan menjadi minimal $80 \%$ untuk jalur zonasi, $15 \%$ jalur prestasi, dan 5\% jalur pindahan orang tua/wali.

Temuan awal kami menunjukkan bahwa PPDB berbasis zonasi di sana berdampak tidak hanya pada karakteristik peserta didik yang diterima sekolah tapi juga proses pembelajaran di kelas. Siswa baru yang diterima melalui PPDB zonasi memang tinggal lebih dekat dengan sekolah negeri dibanding PPDB berbasis prestasi. Namun, komposisi siswa yang diterima melalui sistem zonasi memiliki nilai rendah dan lebih beragam dibandingkan dengan siswa yang diterima melalui sistem prestasi. Keadaan ini menuntut guru-guru di sekolah negeri untuk beradaptasi dengan cepat.

Para guru yang terbiasa mengajar siswa dengan kemampuan rata-rata tinggi, kini harus mengajar siswa dengan nilai rata-rata rendah dengan kemampuan yang sangat beragam. Padahal, keterampilan yang dibutuhkan oleh guru yang mengajar anakanak berkemampuan tinggi dan 
berkemampuan rendah berbeda. Anak-anak berkemampuan tinggi membutuhkan tantangan baru dan pengayaan dari guru agar bisa termotivasi dan meningkatkan kemampuannya. Di sisi lain, anak-anak berkemampuan rendah membutuhkan bantuan guru untuk membangun pemahaman ilmunya dengan benar.

Terlebih lagi, tantangan guru dalam mengajar anak dengan kemampuan beragam lebih berat daripada anak dengan kemampuan yang relatif homogen. Guru yang mengajar kelas yang homogen cenderung dapat mengajarkan seluruh siswa dengan seiring sejalan. Namun, ketika kelas yang diajar relatif heterogen, guru harus menyesuaikan pola mengajar untuk mengakomodasi anak yang cepat dan lambat dalam belajar. Semakin besar kesenjangan kemampuan anak, semakin besar beban guru dalam mengajar.

Masalahnya, penyesuaian kemampuan guru mengajar ini tidak bisa dilakukan dalam waktu singkat. Alhasil, proses pembelajaran di kelas tidak dapat berjalan secara optimal dan menciptakan perubahan situasi dalam proses pembelajaran di kelas. Peran pemerintah melalui pemerintah daerah di kantor cabang Dinas Pendidikan Wilayah VIII dalam mencermati hal tersebut melakukan langkah-langkah berikut ini:

1. Melakukan evaluasi mengenai kesiapan pemerintah daerah dalam pelaksanaan "sistem zonasi" termasuk ketersediaan sekolah di Kabupaten/kota, sehingga dapat diketahui daerah kabupaten/Kota yang kekurangan sekolah;

2. Melalui sistem zonasi ini dalam rangka pemerataan pendidikan yang harus didukung dengan adanya sarana dan prasarana yang memadai di sekolahsekolah, sehingga kekhawatiran orang tua siswa ketika anaknya tidak bersekolah di sekolah dengan fasilitas memadai dapat terjawab dengan adanya dukungan sarana dan prasarana tersebut;

3. Adanya ketersediaan guru secara memadai perlu disosialisasikan kepada masyarakat untuk setiap zona, sehingga mutu pendidikan dengan adanya ketersediaan guru tidak menjadi kekhawatiran masyarakat;

4. Adanya keluhan atas sosilisasi yang tidak memadai dari masyarakat perlu disikapi oleh pemerintah daerah dengan berbagai kanal/akses informasi dan juga ketersediaan informasi baik secara online maupun penyebaran melalui pamflet dan papan pengumuman;

5. Perlunya dipetakan dampak dari sistem zonasi, apakah terdapat sekolah yang "sepi" dari siswa, karena di zona tersebut tidak banyak pemukiman penduduk, sehingga dapat dicarikan solusinya.

Sistem PPDB ditujukan untuk mengurangi segregasi yang berbeda dengan yang didesain untuk meningkatkan efisiensi pembelajaran. Oleh karena itu, untuk mendapatkan tujuan yang tepat, pemerintah 
harus terbuka dalam melihat permasalahan yang ada di lapangan. Dalam konteks PPDB, pemerintah harus memprioritaskan sistem yang efisien dan mengakomodasi kebutuhan masyarakat.

3. Efektifitas pelaksanaan kebijakan sistem zonasi penerimaan siswa baru di era desentralisasi pendidikan

Konsekuensi logis dalam pelaksanaan desentralisasi berdampak pad berbagai sektor, salah satunya adalah sektor pendidikan yang kemudian berkaitan juga dengan sistem pendidikan nasional. Oleh karena itu Pemerintah melakukan penyesuaian melalui UU Nomor 20 Tahun 2003. Substansi yang cukup mendasar terhadap UU Sistem Pendidikan Nasional antara lain:

1. Aspek demokratisasi dan desentralisasi pendidikan

2. Peran serta masyarakat

3. Tantangan global.

Perubahan pengelolaan secara otonom, sekurang-kurangnya dapat memberikan dampak kepada:

1. Perluasaan dan pemerataan akses pendidikan

2. Peningkatan mutu dan relevansi pendidikan

3. Efisiensi keuangan

4. Efisiensi administrasi

Oleh karena itu desentralisasi pendidikan memerlukan landasan demokrasi yang kuat, transparan, efisien serta melibatkan para pemangku kepentingan. Menurut Hadiyanto (2004: 30) secara konseptual, terdapat dua jenis desentralisasi pendidikan, yaitu:

1. Desentralisasi kewenangan di bidang pendidikan dalam hal kebijakan pendidikan dan aspek pendanaannya dari
Pemerintah Pusat ke pemerintah daerah (provinsi, kabupaten/kota)

2. Desentralisasi pendidikan dengan fokus pada pemberian kewenangan yang lebih besar di tingkat sekolah.

Konsep desentralisasi pendidikan yang pertama terutama berkaitan dengan otonomi daerah dan desentralisasi penyelenggaraan pemerintahan dari Pusat ke daerah, sedangkan konsep desentralisasi pendidikan yang memfokuskan pada pemberian kewenangan yang lebih besar pada tingkat sekolah dilakukan dengan motivasi untuk meningkatkan kualitas hasil Pendidikan.

Terkait dengan efektivitas untuk menilai sistem zonasi dalam Penerimaan Peserta Didik Baru (PPDB) dapat dinilai sebagai hal yang kurang efektif untuk dilaksanakan, dan perlu untuk dilakukan perbaikan dan evaluasi, menurut Bapak Muh. Zubaidi selaku Pelaksana Harian Kepala Kantor Cabang Dinas Pendidikan Wilayah VIII mencontohkan yang terjadi di tingkat SMA Negeri di Kota Magelang yang terdiri dari SMA N 1, SMA N 2, SMA N 3, SMA N 4, SMA N 5 ada salah satu SMA Negeri yang mengalami kekurangan siswa padahal sebelum ada sistem zonasi SMA Negeri tersebut menjadi sekolah yang selalu memperoleh siswa sesuai dengan jumlah kuota yang tersedia, permasalahan lain juga terjadi terhadap salah satu siswa yang akan mendaftar di SMA Negeri tujuan tidak dapat diterima karena sudah penuh untuk daya tampungnya, sehingga dengan terpaksa siswa tersebut harus mencari sekolah lain yang berstatus swasta yang mana sekolah 
swasta tidak menerapkan sistem zonasi. Hal ini mengartikan bahwa peran pemerintah pun masih belum optimal dalam melakukan pemerataan kualitas dan mutu pendidikan. Akibatnya saat proses penerimaan siswa baru para siswa cenderung mendafatar di satu sekolah yg diunggulkan di daerah masing-masing. Dan hal ini semakin memperjelas bahwa pendidikan di indonesia masih adanya ketimpangan kualitas pendidikan.

Memang benar jika dengan adanya sistem zonasi akan memberikan keadilan atau pemerataan dan dapat meningkatkan pendidikan yang berkualitas, namun perlu untuk diperhatikan tentang kualitas dan kemampuan siswa dalam mengikuti penerapan kurikulum dan kegiatan belajar mengajar di setiap sekolah, yang mana akan berpengaruh dalam penilaian akreditasi sekolah tersebut. Semakin mampu siswa memahami dalam belajar akan berpengaruh juga dalam guru untuk memberikan pengajarannya, begitu juga sebaliknya semakin baik pengajaran yang dilakukan oleh guru, belum tentu dapat diikuti oleh siswa yang kurang mempu dalam memahami pembelajaran.

\section{SIMPULAN}

Pelaksanaan kebijakan desentralisasi khususnya di SMA Negeri di Kota Magelang tidak terlalu berpengaruh secara siginifikan terhadap jumlah peserta didik baru. Ini dibuktikan dengan adanya peningkatan data prosentasi penerimaan peserta didik.
Selain itu, Bapak Muh. Zubaidi selaku Pelaksana Harian Kepala Kantor Cabang Dinas Pendidikan Wilayah VIII, mengatakan bahwa untuk PPDB di Kota Magelang di tingkat SMA Negeri yang terdiri dari SMA N 1, SMA N 2, SMA N 3, SMA N 4, SMA N 5 Kota Magelang tidak terjadi suatu permasalahan yang signifikan terhadap adanya sistem zonasi di era desentralisasi pendidikan.

Peran pemerintah melalui pemerintah daerah di kantor cabang Dinas Pendidikan Wilayah VIII dalam mencermati hal tersebut melakukan langkah-langkah berikut ini:

1. Melakukan evaluasi mengenai kesiapan pemerintah daerah dalam pelaksanaan "sistem zonasi" termasuk ketersediaan sekolah di Kabupaten/kota, sehingga dapat diketahui daerah kabupaten/Kota yang kekurangan sekolah;

2. Melalui sistem zonasi ini dalam rangka pemerataan pendidikan yang harus didukung dengan adanya sarana dan prasarana yang memadai di sekolahsekolah, sehingga kekhawatiran orang tua siswa ketika anaknya tidak bersekolah di sekolah dengan fasilitas memadai dapat terjawab dengan adanya dukungan sarana dan prasarana tersebut;

3. Adanya ketersediaan guru secara memadai perlu disosialisasikan kepada masyarakat untuk setiap zona, sehingga mutu pendidikan dengan adanya ketersediaan guru tidak menjadi kekhawatiran masyarakat;

4. Adanya keluhan atas sosialisasi yang tidak memadai dari masyarakat perlu disikapi oleh pemerintah daerah dengan berbagai 
kanal/akses informasi dan juga ketersediaan informasi baik secara online maupun penyebaran melalui pamflet dan papan pengumuman;

5. Perlunya dipetakan dampak dari sistem zonasi, apakah terdapat sekolah yang "sepi" dari siswa, karena di zona tersebut tidak banyak pemukiman penduduk, sehingga dapat dicarikan solusinya.

Dengan memperhatikan hal tersebut, maka pelaksanaan kebijakan desentralisasi pendidikan dapat dikatakan lebih efektif dan efisien untuk dunia pendidikan di masa yang akan datang.

\section{DAFTAR RUJUKAN}

Bryson, J.N. 1988. Strategic Planning For Public and Non Profit Organization. San Francisco: Jossey Bass Publishers.

Hadiyanto. 2004. Mencari Sosok Desentralisasi Manajemen Pendidikan di Indonesia. Jakarta: Rineka Cipta.

Satori, Dj. 1999. "Analisis Kebijakan Dalam Konteks Desentralisasi dan Otonomi Pendidikan", Seri Perencanaan Biro Prencanaan Sekretaris Jendera/, Depdiknas, Jakarta.

Toha, Miftah. 1999. "Desentralisasi Pendidikan", Jurnal Pendidikan dan Kebudayaan.

Unit Fasilitasi Desentralisasi Pendidikan. "Desentralisasi Pendidikan", Departemen Pendidikan Nasional, Agustus 2003.

M. Darto, "Prospek dan Tantangan Desentralisasi Pendidikan di Kalimantan Timur", www.samarinda.lan.go.id/jba/index.php/ $\mathrm{jba/article/view/12}$

Undang-Undang Nomor 20 Tahun 2003 tentang Sistem Pendidikan Nasional;
(Lembaran Negara Republik Indonesia Tahun 2003 Nomor 78, Tambahan Lembaran Negara Republik Indonesia Nomor.4301)

Undang-Undang Nomor 23 Tahun 2014 tentang Pemerintahan Daerah; (Lembaran Negara Republik Indonesia Tahun 2014 Nomor 244; Tambahan Lembaran Negara Republik Indonesia Nomor 5587)

Peraturan Menteri Pendidikan dan Kebudayaan Republik Indonesia Nomor 14 Tahun 2018 tentang Penerimaan Peserta Didik Baru Pada Taman Kanak-Kanak, Sekolah Dasar, Sekolah Menengah Pertama, Sekolah Menengah Atas, Sekolah Menengah Kejuruan, Atau Bentuk Lain Yang Sederajat

Peraturan Menteri Pendidikan Dan Kebudayaan Republik Indonesia Nomor 51 Tahun 2018 Tentang Penerimaan Peserta Didik Baru Pada Taman KanakKanak, Sekolah Dasar, Sekolah Menengah Pertama, Sekolah Menengah Atas, Dan Sekolah Menengah Kejuruan

Peraturan Menteri Pendidikan Dan Kebudayaan Republik Indonesia Nomor 20 Tahun 2019 Tentang Perubahan Atas Peraturan Menteri Pendidikan Dan Kebudayaan Nomor 51 Tahun 2018 Tentang Penerimaan Peserta Didik Baru Pada Taman Kanak-Kanak, Sekolah Dasar, Sekolah Menengah Pertama, Sekolah Menengah Atas, Dan Sekolah Menengah Kejuruan 